\title{
PREPARATION OF HIGHLY-CONCENTRATED AUTOLOGOUS PLATELET-RICH PLASMA FOR BIOMEDICAL USE
}

\author{
V. CHERNYSHENKO ${ }^{1 凶}$, K. SHTEINBERG ${ }^{2}$, N. LUGOVSKA ${ }^{1}$, M. RYZHYKOVA ${ }^{1}$, \\ T. PLATONOVA ${ }^{1}$, D. KOROLOVA ${ }^{1}$, E. LUGOVSKOY ${ }^{1}$ \\ ${ }^{1}$ Palladin Institute of Biochemistry, National Academy \\ of Sciences of Ukraine, Kyiv; \\ 凶e-mail: bio.cherv@gmail.com; \\ '2Dr. Zapolska Clinic', Kyiv, Ukraine
}

Received: 21 December 2018; Accepted: 20 March 2019

\begin{abstract}
Cell therapy with platelets is a widely accepted approach for wound healing and tissue regeneration in medicine. However, with most available methods poorly concentrated platelet suspensions (up to 0.3.10 1 / $\mu l)$ or suspensions of mostly inactivated or lost platelets are obtained. In this study, we aimed to develop a simple and effective method for preparing a suspension of native and resting platelets with over 1·10 $1 / \mu l$. Platelet-rich plasma (PRP) was obtained from fresh blood of healthy donors $(n=5)$ collected using different amounts of heparin as the anticoagulant. Samples of PRP were spun down and re-suspended in autologous blood plasma. Count and vitality of platelets in each sample were determined by aggregation study on the Solar AP2110 aggregometer. Platelet shape and cytoplasmic granularity that indicate the nativity of platelets were monitored on the COULTER EPICS XL Flow Cytometer. This study of aggregation of platelets in PRP obtained using various amounts of heparin allowed us to reduce final concentrations to the amount that effectively prevented clotting and did not affect platelet reactivity $(5 \mathrm{U} / \mathrm{ml})$. PRP concentrated 5 times with a total concentration of cells of $1 \cdot 10^{6} 1 / \mu l$ was able to be activated by adenosine diphosphate (ADP) (aggregation rate $54 \pm 7 \%$ ). The amount of cells with altered shape and granularity in concentrated suspension was not higher than 20\%. This finding means that the platelets would still be able to release a number of growth factors and other biologically active compounds after stimulation or injection into tissue during cell therapy. The decrease in heparin concentrations also minimizes haemorrhage in the injection site supporting biomedical use of the suspension. A simple and effective method for preparation of highly-concentrated PRP $\left(1.2 \cdot 10^{6} 1 /\right.$ $\mu l)$ for biomedical use was developed. Aggregometry and flow cytometry proved that obtained platelets were resting and able to be activated. Being autologous, the preparation can be widely used for cell therapy without additional precautions.
\end{abstract}

Keyword s: cell therapy, platelets, autologous, platelet rich plasma, preparation protocol.

A pplication of autologous platelet-rich plasma (PRP) is considered to be beneficial in restoring connective tissues because of the slow delivery of growth factors from the harvested platelets $[1,2]$. Despite the uncertainty about the mechanisms of action of PRP, it is widely used in many fields of medicine, including dermatology, surgery, bone reconstruction, wound healing and aesthetic surgery [3-8]. Moreover, some authors report inefficiency of PRP therapy and assume the positive impact of its application is due to "placebo effects" $[9,11]$.

In our opinion, the reason for varying clinical efficacy in PRP use is the lack of standardization of the PRP preparation [12]. In some of the more recent articles concerning application of PRP, a detailed, precise, and stepwise description of the PRP preparation protocol is claimed to be required to allow

(C) 2019 Chernyshenko V. et al. This is an open-access article distributed under the terms of the Creative Commons Attribution License, which permits unrestricted use, distribution, and reproduction in any medium, provided the original author and source are credited. 
comparison among studies and reproducibility of results $[13,14]$.

In this study, we aimed to develop a simple and effective method of autologous PRP preparation using heparin as an anticoagulant. We also propose a reproducible way to characterize the count and vitality of the resulting PRP that could be applied at all stages of preparation.

\section{Materials and Methods}

Heparin solution (5000 IU/ml) was purchased from Indar (Kyiv, Ukraine). Sodium citrate, HEPES, $\mathrm{NaCl}, \mathrm{KCl}, \mathrm{MgCl}_{2}$, glucose, $\mathrm{NaH}_{2} \mathrm{PO}_{4}$, and BSA were purchased from Sigma-Aldrich (St. Louis, MO, USA).

Adenosine diphosphate (ADP) was purchased from Sigma-Aldrich. The millimolar extinction coefficient of a pH 7 solution of ADP sodium salt is 15.4 at the absorbance maximum wavelength of $259 \mathrm{~nm}$. We recommend preparing a $1.5 \mathrm{mM}$ stock solution of ADP and storing it at $-20{ }^{\circ} \mathrm{C}$. The working solution of ADP must be prepared ex temporo by diluting it $1: 100$ in $0.05 \mathrm{M}$ Tris $\mathrm{HCl}$ buffered with $0.13 \mathrm{M}$ $\mathrm{NaCl}$ (TBS) or PBS (0.01 $\mathrm{M} \mathrm{KH}_{2} \mathrm{PO}_{4} \mathrm{pH}$ 7.4). Furthermore, we recommend using the most simple neutral buffer solution to dissolve ADP for measuring.

Blood sampling. Venous blood of healthy volunteers ( $n=5$; 2 females, 3 males) aged from 25 to 35 years who had not taken any medication for 7 days was obtained by venipuncture of the basilic vein using 19G sterile needles. Blood was collected into sterile plastic $10 \mathrm{ml}$ tubes where it was mixed immediately with $38 \mathrm{~g} / \mathrm{l}$ sodium citrate (SC) (9 parts blood to 1 part SC), heparin at different ratios (final concentrations were 1.5 to $15 \mathrm{IU} / \mathrm{ml}$ for heparin). If the collection is performed using a syringe, we recommend removing the needle before ejecting blood into the tube.

Volunteers signed informed consent prior to blood sampling. All manipulations were conducted under a license of the Ministry of Health of Ukraine AE459095 issued to the Dr. Zapolska Clinic (19.06.2014, N 412).

Aggregometry. Platelet aggregation measurements were based on changes in the turbidity of human PRP [15]. Studies were performed on the Aggregometer Solar AP2110 (Solar, Belorussia) ac- cording to the recommendations of manufacturer. PRP, concentrated platelet suspension or washed platelets (250 ul) were added into the sample tube with a magnetic stirring bar that provided constant mixing during the measuring process. The number of platelets was registered during mixing. After $1 \mathrm{~min}$ of mixing, the platelets were activated by addition of $25 \mu \mathrm{CaCl}_{2}(10 \mu \mathrm{M})$ and $25 \mu \mathrm{l}$ of the platelet agonist ADP $(15 \mu \mathrm{M})$. Aggregation was registered for $5 \mathrm{~min}$. Platelet count was estimated using the same device. The initial rate and final level of aggregation were measured at $37^{\circ} \mathrm{C}$ in $250 \mu$ of PRP.

This method is easy to use and does not require expensive devices. It was successfully used in our laboratory and allowed us to obtain data with high reproducibility [16, 17].

Flow cytometry. Platelets in PRP and concentrated suspensions were characterized by flow cytometry using the COULTER EPICS XL Flow Cytometer (Backman coulter, Ramsey, Minnesota, USA). To make the measurements most cost-effective we avoided the application of specific compounds or antibodies for assessing the shape and granulation of platelets. To make these assessments, we estimated the side light transmission of platelets (SS) to indicate platelet granulation and the frontal light transmission of platelets (FS) to indicate platelet shape. We recommend using logarithmic coordinates for the most effective presentation of the data [18]. This approach was effectively used several times in our studies [19, 20].

Statistics. Results are presented as means \pm standard deviations. The difference between the groups was analyzed by one-way ANOVA. Differences were considered significant for $P<0.05$.

\section{Results and Discussion}

Blood collection - anticoagulant selection. Most authors recommend using SC as the anticoagulant for PRP acquisition. The use of SC allows the most concentrated suspensions of platelets with the highest content of growth factors to be obtained [21, 22]. Most blood collection and centrifugation protocols for obtaining PRP use acid citrate dextrose (ACD) or SC as an anticoagulant [23].

However, SC causes pain during injection and is avoided by doctors, especially in aesthetic medi-

Abbreviations: PRP - platelet-rich plasma; RCF - relative centrifugal force; RPM - rotation per minute; SC - sodium citrate; ADP - adenosine diphosphate; FS - frontal light transmission of platelets; SS - side light transmission of platelets (SS). 
cine $[24,25]$. The use of a citrate-free formulation was considered a very positive change due to the disappearance of pre-administration anxiety [26]. Possibly it is one of a reasons some authors report the use of heparin as an effective anticoagulant for PRP preparation [27, 28]. Heparin was also shown to preserve platelet function for a longer time than SC [29]. Yet most studies show heparin activates platelets [30]. The mechanism of this action consists in direct binding of heparin to GPIIb-IIIa, triggering a signaling cascade that leads to activation of phosphatidyl-inositol-3 kinase [31].

To select the dosage of heparin that effectively prevents blood clotting but does not activate platelets during PRP preparation, we collected blood of donors in sample tubes with different amounts of anticoagulant and then analyzed platelet aggregation in PRP (Fig. 1).

Most systems for blood collection use 10 to $50 \mathrm{IU} / \mathrm{ml}$ heparin [32]. As shown in Fig. 2 (A), heparin concentrations above $10 \mathrm{IU} / \mathrm{ml}$ led to a three-fold or more decrease in the platelet aggregation rate due to the action of heparin. On the other hand, at a final concentration of heparin lower than $4 \mathrm{IU} / \mathrm{ml}$, we also observed decreasing platelet reactivity that was caused by blood coagulation cascade activation during sample collection. At the final concentration of anticoagulant lower than $1.5 \mathrm{IU} / \mathrm{ml}$, blood clotting was observed. We recommend using 5-8 IU/ml of heparin as the anticoagulant for effectively preventing the clotting of collected blood without affecting platelet reactivity.

However, all our previous studies of PRP had the best results when we used SC as the anticoagulant [18-22]. We recommend using SC when possible, for example for scientific purposes.

Blood centrifugation. PRP was obtained by centrifugation of blood at $200 \mathrm{~g}$ for $30 \mathrm{~min}$ at $25^{\circ} \mathrm{C}$. For centrifugation we recommend using the same plastic tube that was used for blood collection. A yellowish initial PRP with the number of platelets from 0.15 to $0.35 \cdot 10^{6} 1 / \mu \mathrm{l}$ can be found above the red phase of blood cells. This initial PRP can be used for laboratory testing of platelet reactivity or to perform experiments. We used this initial PRP to concentrate the platelet suspension.

We performed centrifugation and calculated the relative centrifugal force (RCF, g). In the scientific literature about the preparation of PRP, we noticed that many authors use RPM (rotation per minute) as the unit of measure [33]. Although this approach

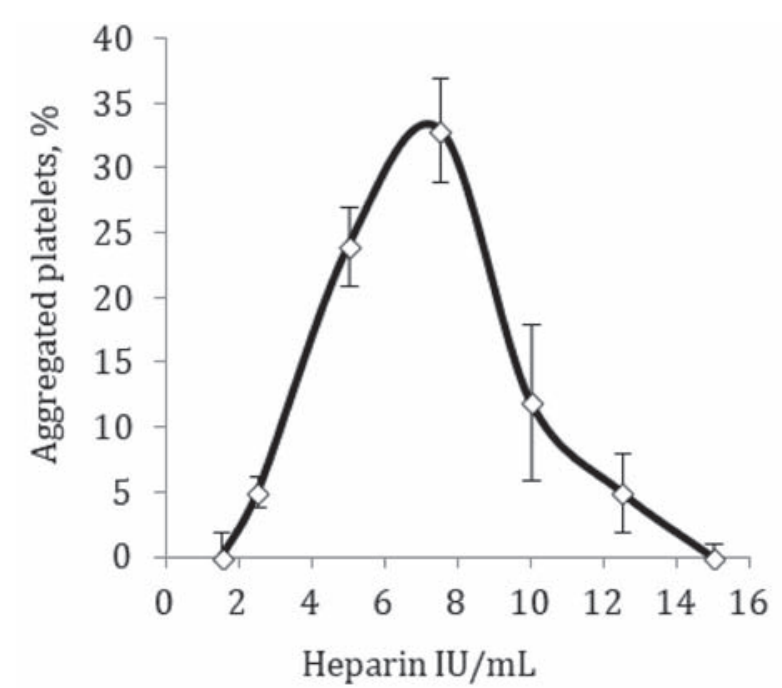

Fig. 1. Platelet aggregation rate in platelet-rich plasma (PRP) derived from blood collected using heparin as the anticoagulant. $P \leq 0.05, n=5$

is very useful inside a laboratory, it is a wrong approach for achieving standardization. Calculation of RCF allows the determination of the desirable speed of centrifugation for every centrifuge. In Fig. 2, we present simple diagrams for a quick calculation of the RPM needed to achieve an RCF of $200 \mathrm{~g}$ (Fig. 2, $B$ ) and 450 g (Fig. 2, B); these diagrams were created using formula presented previously [34].

PRP normally obtained after a single centrifugation contains $0.15-0.35 \cdot 10^{6} 1 / \mu \mathrm{l}$. However, to achieve the therapeutic effect the PRP must be concentrated up to $1.0 \cdot 10^{6} 1 / \mu l$ [35]. There are two main approaches for achieving this. One approach is to use kits for preparation of highly concentrated PRP. There are several commercially available systems for PRP preparation that differ in yield, the anticoagulant used or efficacy [36]. In the other approach, here we obtained highly concentrated PRP by differential centrifugation. However, these methods generally are not described well and are very difficult to standardize, and the preparation process is not characterized [15].

Concentrating of the platelet suspension in autologous blood plasma. We aimed to concentrate platelets in autologous blood plasma. In the series of experiments we spun down $1.5 \mathrm{ml}$ of the initial PRP by centrifugation at $400 \mathrm{~g}$ during $10 \mathrm{~min}$ at $25^{\circ} \mathrm{C}$. Such a speed is less traumatic for platelets, although we were concerned that some portion of the platelets was lost during the procedure. Platelet-poor plasma that was observed over the platelet pellet was re- 
A

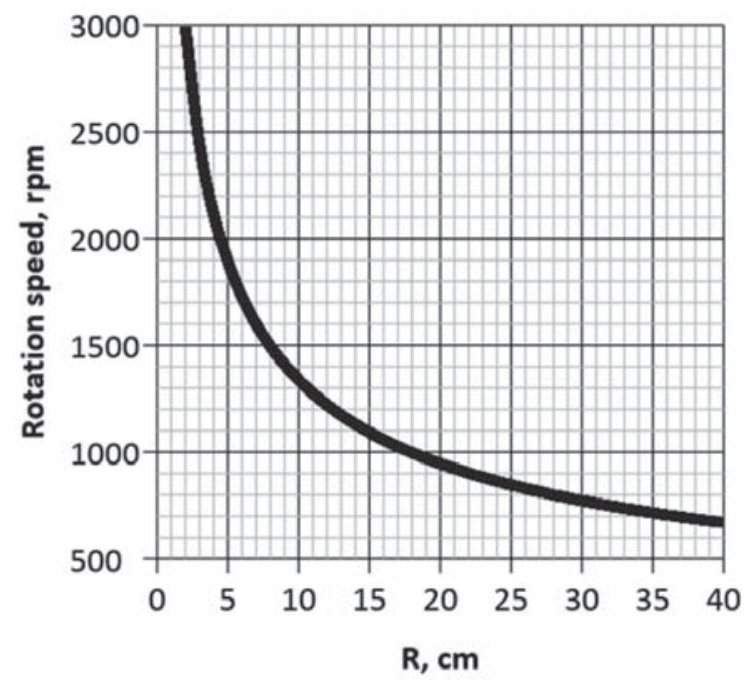

B

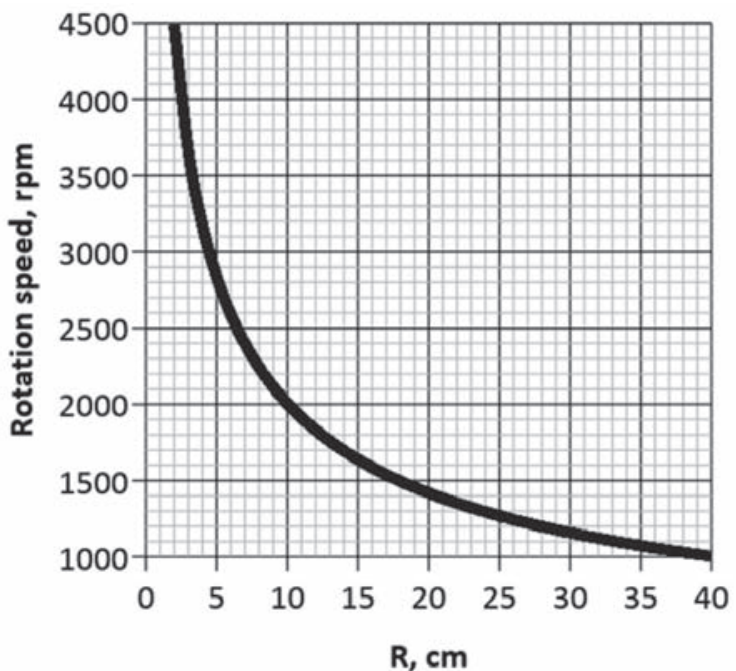

Fig. 2. Calibration curves for calculation of rotation per minute (RPM) for centrifuges with different rotor radiuses (the radius can be found in the passport of the centrifuge). $\boldsymbol{A}$-Calculation of RPM that is needed to achieve a relative centrifugal force (RCF) of $200 \mathrm{~g}$, given the rotor radius (R). B -Calculation of $R P M$ that is needed to achieve a relative centrifugal force (RCF) of $450 \mathrm{~g}$, given the rotor radius $(R)$

moved to a sterile plastic tube. Platelet pellets were re-suspended in autologous blood plasma (from 1.0 to $0.1 \mathrm{ml}$ ) by gentle pipetting.

The summarized step-by-step process for preparation of highly concentrated PRP including two-step centrifugation at 200 and $450 \mathrm{~g}$ is presented in Fig. 3.

Characterization of concentrated platelet suspensions. To characterize the vitality of platelets during the concentration process we analyzed the shape and the granulation of platelets by flow cytometry and their ability to aggregate using aggregometry.

Flow cytometry measurements were based on the fact that platelet activation leads to degranulation and pseudopodia formation, thus resting and activated cells can be easily separated according to these parameters [37]. Data presented in Fig. 4 demonstrate that concentration of platelets and their further resuspension in autologous blood plasma leads to moderate activation of cells. Maximal concentrated platelets suspension $\left(A, 0.1-1.2 \cdot 10^{6} 1 / \mu \mathrm{l}\right)$ contained at least $15 \pm 5.4 \%$ of cells with changed shape or granularity.

Data of aggregometry presented in Fig. 4 (panel $B$ ) demonstrated that platelets in concentrated suspensions were able to aggregate under the action of ADP. Aggregation rate was slightly decreased when platelets were spun down and re-suspended again without much increase in their number. Further concentration of platelets led to an increase in their overall ability to aggregate. The approximate number of platelets in the suspension concentrated from different volumes of initial PRP can be predicted according to Table.

Concentration of platelet suspension in HEPES-buffer. When the concentration of platelets in autologous blood plasma is important for medi-

Approximate parameters of $1 \mathrm{ml}$ of highly concentrated platelet-rich blood plasma derived from different amounts of initial non-concentrated PRP.

\begin{tabular}{l|c|c|c|c|c}
\hline \multirow{2}{*}{\multicolumn{1}{c}{ Parameters }} & \multirow{2}{*}{ Control } & \multicolumn{3}{c}{ Starting volume of non-concentrated PRP, ml } \\
\cline { 3 - 6 } & & 1.5 & 3.75 & 7.5 & 15 \\
\hline Aggregation rate, \% & $35 \pm 3$ & $20 \pm 8$ & $40 \pm 10$ & $45 \pm 8$ & $54 \pm 7$ \\
Resting cells, \% & $10 \pm 2$ & $11 \pm 2$ & $10 \pm 5$ & $12 \pm 4$ & $15 \pm 5.4$ \\
Number of platelets, $\times 10^{6} 1 / \mu \mathrm{ll}$ & $0.21 \pm 0.03$ & $0.31 \pm 0.06$ & $0.5 \pm 0.1$ & $0.72 \pm 0.10$ & $1.20 \pm 0.09$ \\
\hline
\end{tabular}




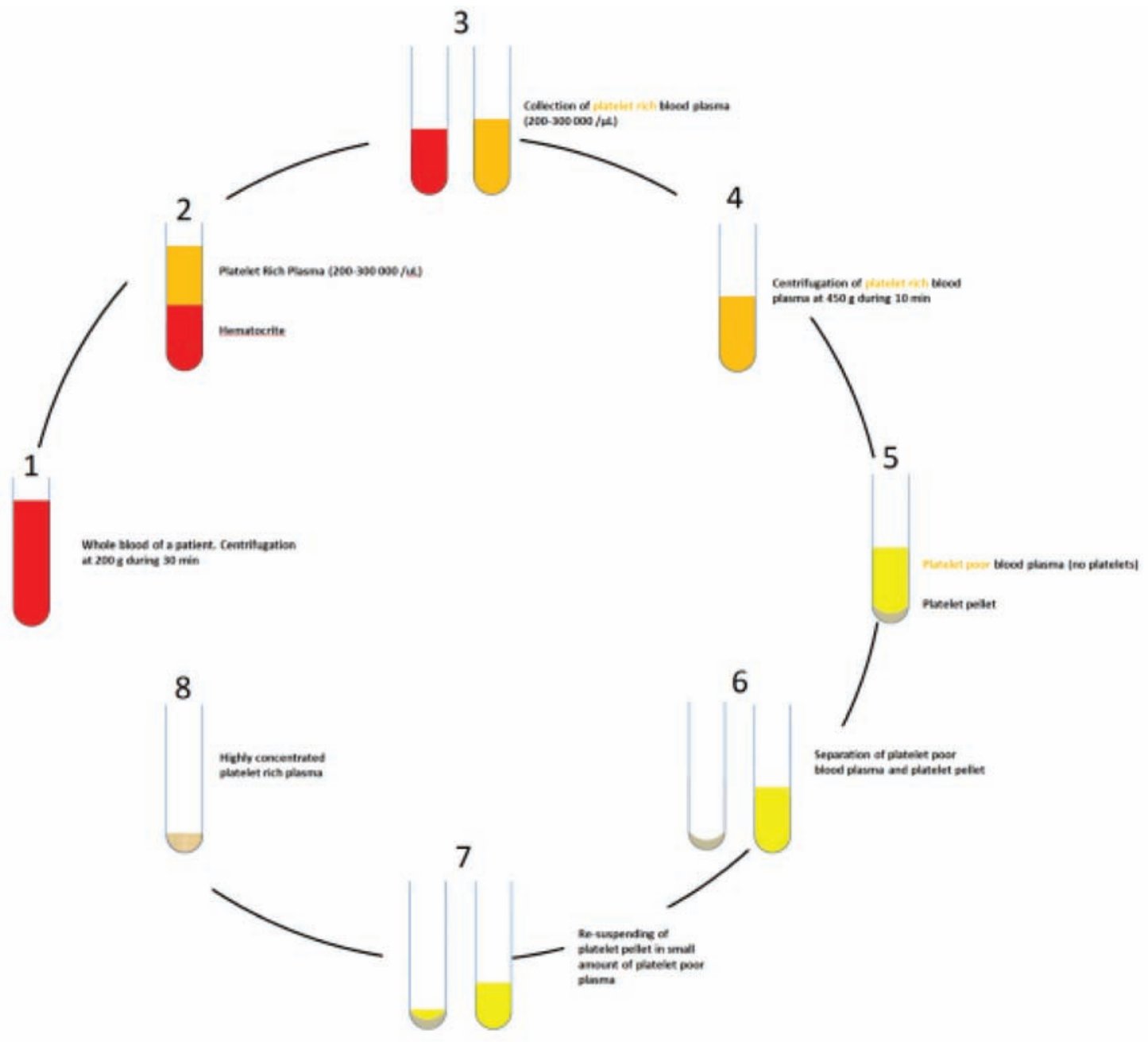

Fig. 3. Process of preparation of highly concentrated platelet-rich plasma (PRP). 1 -donor's blood collected in the plastic tube with $0.38 \%$ sodium citrate (SC) or $5 \mathrm{IU} / \mathrm{ml}$ heparin. Centrifugation of blood at $200 \mathrm{~g}$ during 30 min; 2 - hematocrite and PRP (concentration of platelets $0.2-0.3 \cdot 10^{6} 1 / \mathrm{ml}$ ); 3 -PRP separated from hematocrite in sterile plastic tube; 4 - centrifugation of PRP at $450 \mathrm{~g}$ during $10 \mathrm{~min} ; \mathbf{5}$ - platelet pellet and platelet-poor plasma above it; $\mathbf{6}$ - separation of platelet-poor plasma from platelet pellet; $\mathbf{7}$ - re-suspension of platelet pellet in small amount of platelet-poor plasma that was collected in p. step 6. It is more useful to leave the desirable amount of platelet-poor plasma in the same tube with platelet plasma and resuspend the pellet in it; $\boldsymbol{8}$ - highly concentrated PRP

cal use, the experimental research often requires removal of most blood compounds. In this study we concentrated platelets in different amounts of buffer saline to prepare so-called "washed" platelets. HEPES buffer that was used for this purpose contained 0.004 M HEPES, 0.137 M NaCl, 0.0027 M $\mathrm{KCl}, 0.001 \mathrm{M} \mathrm{MgCl}_{2}, 0.0056 \mathrm{M}$ glucose, $0.003 \mathrm{M}$ $\mathrm{NaH}_{2} \mathrm{PO}_{4}, 0.35 \mathrm{mg} / \mathrm{ml}$ BSA, pH 7.4.

In the case of resuspending platelets in the HEPES buffer (Fig. 5) the amount of changed cells (activated or pre-activated platelets) was $40 \pm 10 \%$ at maximal concentration $\left(C, 0.1-1.05 \cdot 10^{6} 1 / \mu \mathrm{l}\right)$. Howe- ver, simply removing blood plasma and resuspending the pellet in HEPES buffer did not cause activation of more than $22 \pm 6 \%$ of platelets even at a concentration up to $0.6 \cdot 10^{6} 1 / \mu l$.

Conclusion. A simple and effective method for preparation of highly-concentrated $\left(1.2 \cdot 10^{6} 1 / \mu l\right)$ for biomedical use was developed. Aggregometry and flow cytometry proved that obtained platelets were resting and able to be activated. Being autologous, the preparation can be widely used for cell therapy without additional precautions. 
A

Control

1.0
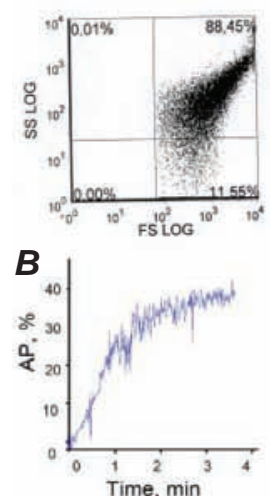
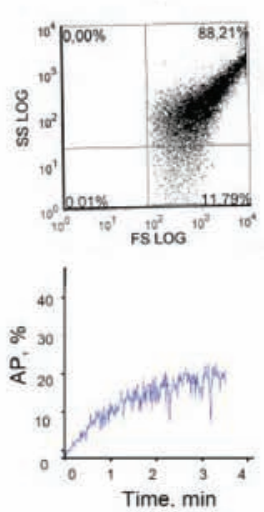

0.8
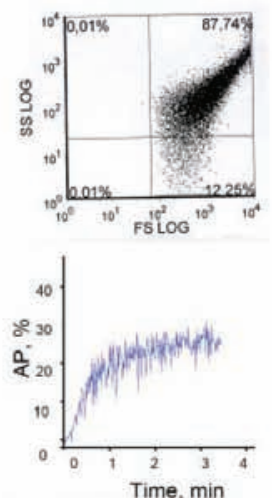

0.4
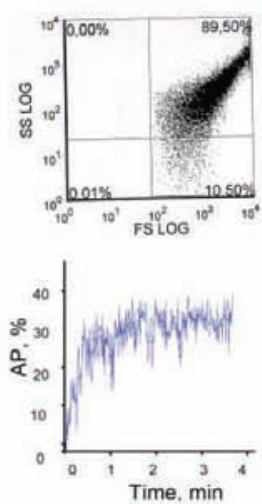

0.2
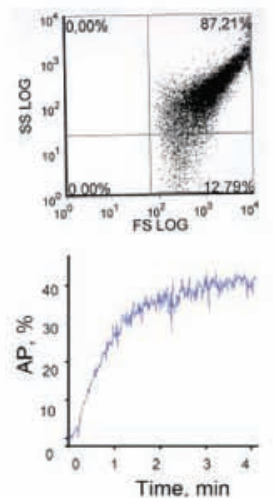

0.1
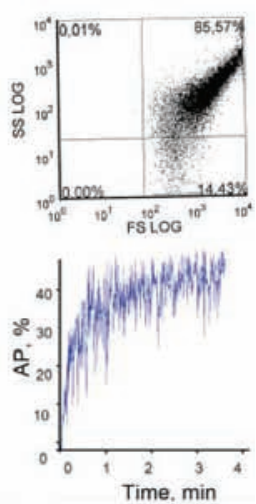

Fig. 4. Flow cytometry and aggregometry of platelets that were spun down and re-suspended in autologous blood plasma during their concentration. Data from typical experiments, $n=5$. AP-aggregated platelets. A - Flow cytometry. Control - shape and granulation distribution of non-concentrated platelets (1.5 ml); 1.00.1 - platelet shape and granulation distribution in suspensions of platelets prepared in the volume of 1, 0.8, 0.4, 0.2, $0.1 \mathrm{ml}$ respectively. Frontal light transmission (FS) - parameter of platelet shape; Side light transmission (SS) - parameter of platelet granulation. Non-stimulated platelets were analyzed. B-Aggregometry. Control - platelet aggregation rate of non-concentrated platelets (1.5 $\mathrm{ml}) ; 1.0-0.1$ - platelet aggregation rate in suspensions of platelets prepared in the volume of 1, 0.8, 0.4, 0.2, $0.1 \mathrm{ml}$ respectively. Platelets were stimulated with adenosine diphosphate (ADP) at the end concentration of $1.25 \mu \mathrm{M}$
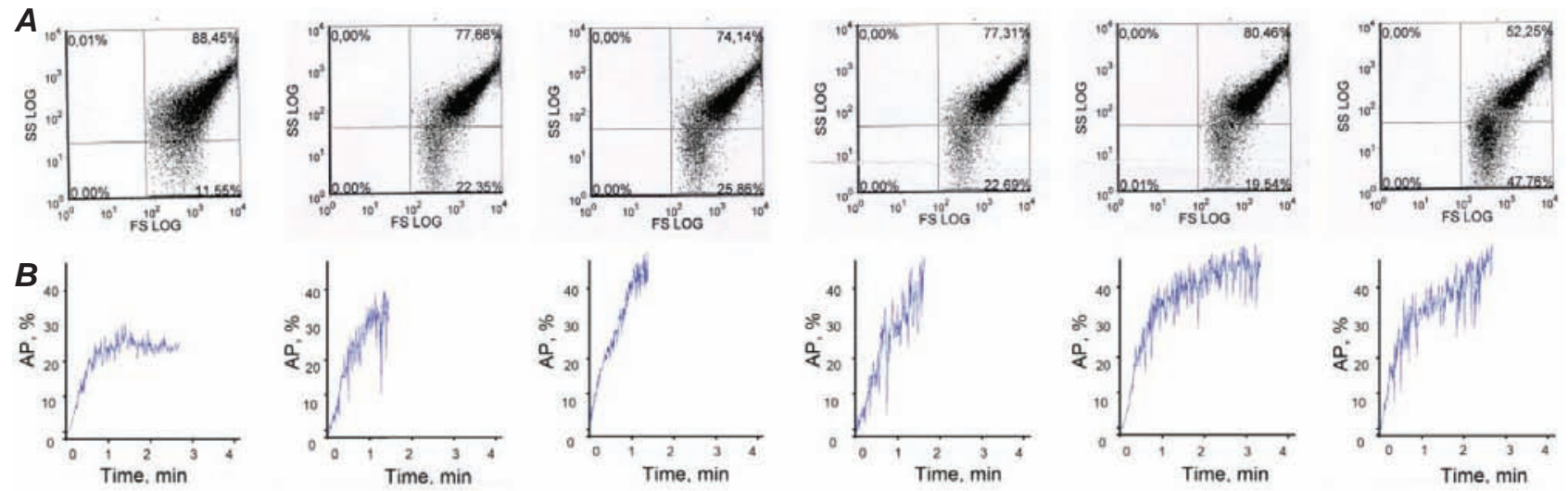

Fig. 5. Flow cytometry and aggregometry of platelets that were spun down and re-suspended in HEPES buffer (0.004 M HEPES, $0.137 \mathrm{M} \mathrm{NaCl}, 0.0027 \mathrm{M} \mathrm{KCl}, 0.001 \mathrm{M} \mathrm{MgCl}_{2}, 0.0056 \mathrm{mM}$ glucose, $0.003 \mathrm{M} \mathrm{NaH}_{2} \mathrm{PO}_{4}$, $0.35 \mathrm{mg} / \mathrm{ml}$ BSA, $p H$ 7.4). Data from typical experiments, $n=5$. AP - aggregated platelets. $\boldsymbol{A}-$ Flow cytometry. Control - shape and granulation distribution of non-concentrated platelets (1.5 ml); 1.0-0.1 - platelet shape and granulation distribution in suspensions of platelets prepared in the volume of 1, 0.8, 0.4, 0.2, $0.1 \mathrm{ml}$ respectively. Frontal light transmission (FS) - parameter of platelet shape; Side light transmission (SS) - parameter of platelet granulation. Non-stimulated platelets were analyzed. $\boldsymbol{B}$-Aggregometry. Control - platelet aggregation rate of non-concentrated platelets $(1.5 \mathrm{ml}) ; 1.0-0.1$ - platelet aggregation rate in suspensions of platelets prepared in the volume of 1, 0.8, 0.4, 0.2, $0.1 \mathrm{ml}$ respectively. Platelets were stimulated with adenosine diphosphate $(A D P)$ at the end concentration of $1.25 \mu \mathrm{M}$

Conflict of interests. The method presented in this study can be commercially used only under the license of the Palladin Institute of Biochemistry of NAS of Ukraine. No. u201810476, IPC (2018.01)
A61K 35/19. Lugovskoi E.V., Chernyshenko V.O., Korolova D.S., Steinberg K.M. Method of preparation of highly concentrated platelet rich human blood plasma. - prior. date 2018.10.24. 
Acknowledgements. This publication contains the results of studies conducted by the support of the President's of Ukraine's scholarship for young scientists (2017-2018). Studies were partially funded by Development project of National Academy of Sciences of Ukraine - 2019. We thank Cedars-Sinai Medical Center's International Research and Innovation in Medicine Program, the Association for Regional Cooperation in the Fields of Health, Science and Technology (RECOOP HST Association) for their support of our organization as a participating Cedars-Sinai Medical Center - RECOOP Research Centers (CRRC).

\section{ПРИГОТУВАННЯ ВИСОКОКОНЦЕНТРОВАНОЇ АВТОЛОГІЧНОЇ ПЛАЗМИ КРОВІ, ЗБАГАЧЕНОЇ ТРОМБОЦИТАМИ, ДЛЯ БІОМЕДИЧНОГО ВИКОРИСТАННЯ}

\author{
B. Чернишенко ${ }^{1 凶}$, К. Штайнберг ${ }^{2}$, \\ Н. Луговська ${ }^{1}$, М. Рижикова ${ }^{1}$, \\ Т. Платонова ${ }^{1}$, Д. Корольова ${ }^{1}$, \\ Е. Луговськой
}

${ }^{1}$ Інститут біохімії ім. О. В. Палладіна НАН України, Київ;

${ }^{\bowtie}$ e-mail: bio.cherv@gmail.com;

${ }^{2}$ «Клініка доктора Запольскої», Київ, Україна

Клітинна терапія 3 використанням тромбоцитів є широко поширеним підходом в медицині для загоєння ран і регенерації тканин. Однак, найдоступніші методи дають змогу отримати не достатньо концентровані суспензії тромбоцитів (до $0,3 \cdot 10^{6}$ 1/мкл) або суспензії тромбоцитів, що частково або повністю втратили свою активність. У цьому дослідженні ми поставили за мету розробити простий та ефективний метод приготування суспензії нативних та інтактних тромбоцитів у концентрації понад $1 \cdot 10^{6}$ 1/мкл. Збагачену тромбоцитами плазму крові (ЗТПК) отримували зі свіжої крові здорових донорів $(n=5)$, при заборі крові як антикоагулянт використовували гепарин. Зразки ЗТПК осаджували і ресуспендували в автологічній плазмі крові. Кількість та життєздатність тромбоцитів у кожному зразку визначали шляхом дослідження агрегації на агрегометрі Solar AP2110. Форма тромбоцитів і гранулярність цитоплазми, які вказують на нативність тромбоцитів, контролювали на потоковому цитометрі COULTER
EPICS XL. Дослідження агрегації тромбоцитів у ЗТПК, отриманій з використанням різних кількостей гепарину, дозволило нам знизити кінцеві концентрації до кількості, яка ефективно запобігала зсіданню крові і не впливала на активність тромбоцитів (5 U/мл). ЗТПК, сконцентрована в 5 разів із загальною концентрацією клітин $1 \cdot 10^{6}$ 1/мкл, була здатна до активації аденозиндифосфатом (АДФ) (ступінь агрегації $54 \pm 7 \%$ ). Кількість клітин зі зміненою формою та гранулярністю в сконцентрованій суспензіі не перевищувала 20\%. Ці дані свідчать, про те, що тромбоцити зберігають здатність вивільняти ряд факторів росту та інші біологічно активні сполуки після стимуляції або ін'єкції в тканини за клітинної терапії. Зниження концентрації гепарину до того ж мінімізує крововилив в місці ін'єкції, що сприяє біомедичному застосуванню суспензії. Розроблено простий та ефективний метод приготування висококонцентрованої ЗТП $\left(1,2 \cdot 10^{6}\right.$ 1/мкл) для біомедичного використання. Агрегатометрія і протокова цитометрія довели, що одержані тромбоцити інтактні й здатні активуватися. Препарат, що $є$ автологічним, може бути широко використаний для клітинної терапії без додаткових запобіжних заходів.

К лючов в слов а: клітинна терапія, тромбоцити, автологічний, збагачена тромбоцитами плазма, протокол приготування.

\section{References}

1. Dhillon RS, Schwarz EM, Maloney MD. Plateletrich plasma therapy - future or trend? Arthritis Res Ther. 2012; 14(4): 219.

2. Galliera E, Corsi MM, Banfi G. Platelet rich plasma therapy: inflammatory molecules involved in tissue healing. J Biol Regul Homeost Agents. 2012; 26(2 Suppl 1): 35S-42S.

3. Arshdeep, Kumaran MS. Platelet-rich plasma in dermatology: boon or a bane? Indian J Dermatol Venereol Leprol. 2014; 80(1): 5-14.

4. Singhal P, Agarwal S, Dhot PS, Sayal S. Efficacy of platelet-rich plasma in treatment of androgenic alopecia. Asian J Transfus Sci. 2015; 9(2): 159162.

5. Frautschi RS, Hashem AM, Halasa B, Cakmakoglu C, Zins JE. Current Evidence for Clinical Efficacy of Platelet Rich Plasma in Aesthetic Surgery: A Systematic Review. Aesthet Surg J. 2017; 37(3): 353-362. 
6. Glynn LG, Mustafa A, Casey M, Krawczyk J, Blom J, Galvin R, Hannigan A, Dunne CP, Murphy AW, Mallen C. Platelet-rich plasma (PRP) therapy for knee arthritis: a feasibility study in primary care. Pilot Feasibility Stud. 2018; 4: 93.

7. Intini G. The use of platelet-rich plasma in bone reconstruction therapy. Biomaterials. 2009; 30(28): 4956-4966.

8. Chicharro-Alcántara D, Rubio-Zaragoza M, Damiá-Giménez E, Carrillo-Poveda JM, Cuervo-Serrato B, Peláez-Gorrea P, SopenaJuncosa JJ. Platelet Rich Plasma: New Insights for Cutaneous Wound Healing Management. J Funct Biomater. 2018; 9(1). pii: E10.

9. Keene DJ, Alsousou J, Willett K. How effective are platelet rich plasma injections in treating musculoskeletal soft tissue injuries? BMJ. 2016; 352: i517.

10. Bell KJ, Fulcher ML, Rowlands DS, Kerse N. Impact of autologous blood injections in treatment of mid-portion Achilles tendinopathy: double blind randomised controlled trial. BMJ. 2013; 346: f2310.

11. Grassi A, Napoli F, Romandini I, Samuelsson K, Zaffagnini S, Candrian C, Filardo G. Is PlateletRich Plasma (PRP) Effective in the Treatment of Acute Muscle Injuries? A Systematic Review and Meta-Analysis. Sports Med. 2018; 48(4): 971-989.

12. Fitzpatrick J, Bulsara MK, McCrory PR, Richardson MD, Zheng MH. Analysis of Platelet-Rich Plasma Extraction: Variations in Platelet and Blood Components Between 4 Common Commercial Kits. Orthop J Sports Med. 2017; 5(1): 2325967116675272.

13. Chahla J, Cinque ME, Piuzzi NS, Mannava S, Geeslin AG, Murray IR, Dornan GJ, Muschler GF, LaPrade RF. A Call for Standardization in Platelet-Rich Plasma Preparation Protocols and Composition Reporting: A Systematic Review of the Clinical Orthopaedic Literature. $J$ Bone Joint Surg Am. 2017; 99(20): 1769-1779.

14. Gómez LA, Escobar M, Peñuela O. Standardization of a Protocol for Obtaining Platelet Rich Plasma from blood Donors; a Tool for Tissue Regeneration Procedures. Clin Lab. 2015; 61(8): 973-980.

15. Cattaneo M, Cerletti C, Harrison P, Hayward CP, Kenny D, Nugent D, Nurden P, Rao AK, Schmaier AH, Watson SP, Lussana F,
Pugliano MT, Michelson AD. Recommendations for the Standardization of Light Transmission Aggregometry: A Consensus of the Working Party from the Platelet Physiology Subcommittee of SSC/ISTH. J Thromb Haemost. 2013; 11(6): 1183-1189.

16. Chernyshenko V, Petruk N, Korolova D, Kasatkina L, Gornytska O, Platonova T, Chernyshenko T, Rebriev A, Dzhus O, Garmanchuk L, Lugovskoy E. Antiplatelet and anti-proliferative action of disintegrin from Echis multisquamatis snake venom. Croat Med J. 2017; 58(2): 118-127.

17. Korolova DS, Chernyshenko TM, Gornytska OV, Chernyshenko VO, Platonova TN. Meizothrombin preparation and its role in fibrin formation and platelet aggregation. Adv Biosci Biotechnol. 2014; 5(7): 588-595.

18. Gryshchuk V, Galagan N. Silica Nanoparticles Effects on Blood Coagulation Proteins and Platelets. Biochem Res Int. 2016; 2016: 2959414.

19. Chernyshenko V, Platonova T, Makogonenko Y, Rebriev A, Mikhalovska L, Chernyshenko T, Komisarenko S. Fibrin(ogen)olytic and platelet modulating activity of a novel protease from the Echis multisquamatis snake venom. Biochimie. 2014; 105: 76-83.

20. Korol'ova DS, Chernyshenko VO, Hornyts'ka OV, Platonova TM. Influence of prothrombin cleavage products on platelet activation and aggregation. Ukr Biokhim Zhurn. 2009; 81(5): 58-65. (In Ukrainian).

21. do Amaral RJ, da Silva NP, Haddad NF, Lopes LS, Ferreira FD, Filho RB, Cappelletti PA, de Mello W, Cordeiro-Spinetti E, Balduino A. Platelet-rich plasma obtained with different anticoagulants and their effect on platelet mumbers and mesenchymal stromal cells behavior in vitro. Stem Cells Int. 2016; 2016: 7414036.

22. Hua L, Lai G, Zhenjun L, Guie M.The study of anticoagulants selection in platelet-rich plasma preparation. Zhonghua Zheng Xing Wai Ke Za Zhi. 2015; 31(4): 295-300. (In Chinese).

23. Alves R, Grimalt R. A review of platelet-rich plasma: history, biology, mechanism of action, and classification. Skin Appendage Disord. 2018; 4(1): 18-24.

24. Laursen T, Hansen B, Fisker S. Pain perception after subcutaneous injections of media containing different buffers. Basic Clin Pharmacol Toxicol. 2006; 98(2): 218-221. 
25. Yu AW, Leung CB, Li PK, Lui SF, Lai KN. Pain perception following subcutaneous injections of citrate-buffered and phosphate-buffered epoetin alpha. Int J Artif Organs. 1998; 21(6): 341-343.

26. Gely C, Marin L, Gordillo J, Mañosa M, Bertoletti F, Cañete F, Gonzalez-Muñosa C, Cabré E, Domènech E, Garcia-Planella E. N032 Impact of pain due to subcutaneous administration of a biological drug. J Crohn's Colitis. 2018; 12(Suppl 1): S582-S583.

27. Fukaya M, Ito A. A new economic method for preparing platelet-rich plasma. Plast Reconstr Surg Glob Open. 2014; 2(6): e162.

28. Biloklytska GF, Kopchak OV, Dieiev VA, Rozdobudko NI. New algorithm of injection PRP-therapy in parodontology. J Educ Health Sport. 2017; 7(10): 198-206.

29. Truss NJ, Armstrong PC, Liverani E, Vojnovic I, Warner TD. Heparin but not citrate anticoagulation of blood preserves platelet function for prolonged periods. $J$ Thromb Haemost. 2009; 7(11): 1897-1905.

30. Greinacher A. Platelet activation by heparin. Blood. 2011; 117(18): 4686-4687.

31. Gao C, Boylan B, Fang J, Wilcox DA, Newman DK, Newman PJ. Heparin promotes platelet responsiveness by potentiating $\alpha \mathrm{IIb} \beta 3$ mediated outside-in signaling. Blood. 2011; 117(18): 4946-4952.
32. Buechler KF, Nakamura KK. More on troponin assays and heparin. Clin Chem. 2001; 47(1): 144147.

33. Kramer ME, Keaney TC. Systematic review of platelet-rich plasma (PRP) preparation and composition for the treatment of androgenetic alopecia. J Cosmet Dermatol. 2018; 17(5): 666671.

34. Data for biochemical research (third edition) by Dawson RM, Elliott DC, Elliott WH, Jones KM. pp 580. Oxford Science Publications, OUP, Oxford, 1986. ISBN 0-19-855358-7 - Wood 1987 - Biochemical Education - Wiley Online Library.

35. Marx RE. Platelet-rich plasma (PRP): what is PRP and what is not PRP? Implant Dent. 2001; 10(4): 225-228.

36. Oudelaar BW, Peerbooms JC, Huis In 't Veld R, Vochteloo AJH. Concentrations of Blood Components in Commercial Platelet-Rich Plasma Separation Systems: A Review of the Literature. Am J Sports Med. 2019; 47(2): 479487.

37. Downing SR, Klement GL. Isolation and proteomic analysis of platelets by SELDI-TOF MS. Methods Mol Biol. 2012; 818: 153-170. 